\title{
ПРАВОВИЙ СТАТУС ПРОМИСЛОВОЇ ВЛАСНОСТІ СУБ'СКТІВ ГОСПОДАРЮВАННЯ
}

\section{ЛАРІН Владислав Олегович - аспірант кафедри господарського та трудового права Інституту права МАУП}

DOI 10.32782/EP.2021.4.24

Метою вдосконалення організачї діяльності підприємств, суб’єктів господарювання має стати завдання нарошування їх інтелектуального потенціалу, інтелектуальной, промислової власності. Організачійним засобом вирішення изого завдання, забезпечення досягнення иілей підвищення частки IB у структурі активів підприємства має стати право, відповідні законодавчі норми. У той же час иинне законодавство України, зокрема господарсъке законодавство, не створюе найбільш сприятливий клімат для забезпечення економічної конкуренцӥ продукціӥ за рахунок нарошування промислової власності.

Аналіз цивільного $i$ господарського законодавства свідчить, що основну увагу ие законодавство приділяе регламентаиї статусу майна (матеріальним активам) особи, відповідним правовідносинам. Значна кількість положень ГКУ, присвячених промисловій власності, носить декларативний характер, не відповідають вимогам повноти, несуперечливості правового регулювання. Необхідно наповнити основний, базовий документ господарсъкого законодавства - Господарсъкий кодекс не тільки поняттями, а й ефективними організачійними механізмами забезпечення інноваційного розвитку, досягнення иілей підвищення частки IB у структурі активів підприємства. У Господарсъкому кодексі мають міститися положення, спрямовані на ебективну регламентацію всіх етапів життєдіяльності інновачій, забезпечення режиму найбільшого сприяння нарошуванню інтелек- туального капіталу, розвитку промислової власності та ї̈ захисту.

Ключові слова: суб’єкти господарювання, інтелектуальна власність, промислова власність, суспільство знань, право власності, патентне законодавство, законодавство про засоби індивідуалізащї, законодавство про недобросовісну конкуренцію.

Обгрунтування актуальності вирішення проблеми дослідження

На сучасному етапі переходу до інформаційного суспільства, суспільства знань у провідних країнах світу інтелектуальна власність розглядається як головна складова національного багатства, головний чинник економічного розвитку. Тобто не матеріальні чи сировинні ресурси, а саме інтелектуальний потенціал стає, в міру просування економіки до більш наукоємної моделі розвитку, визначальним фактором успішності країни, її виживання і процвітання у сьогоднішньому глобалізованому світі. Інтелектуальна власність (IB) стає одним з основних активів підприємства. Як стверджує В. Д. Дюндін, чим ефективніше працює підприємство, тим частка IB у структурі його активів вища [1]. Якщо це так (а це дійсно так), то справедливим $є$ i зворотне твердження: шляхом підвищення частки IB в структурі активів підприємства можна досягти підвищення ефективності його функціонування. Отже, метою вдосконалення організації діяльності підприємств, суб'єктів господарювання має 


\section{Цивільне, підприсмницьке, господарське та трудове право}

стати завдання нарощування їх інтелектуального потенціалу, інтелектуальної, промислової власності. Організаційним засобом вирішення цього завдання, забезпечення досягнення цілей підвищення частки IB у структурі активів підприємства має стати право, відповідні законодавчі норми. У той же час чинне законодавство України, зокрема, господарське законодавство, не створює найбільш сприятливий клімат для забезпечення економічної конкуренції продукції за рахунок нарощування промислової власності. Це є дуже актуальною проблемою, на вирішення якої спрямоване це дослідження.

\section{Стан дослідженості проблеми}

За останні роки посилення європейської інтеграції нашої держави, усе більше коло науковців різних галузей науки звертає свою увагу до досліджень інтелектуальної власності у сфері господарювання. Беззаперечний вклад у дослідження порушеної цієї проблематики внесено такими вітчизняними науковцями, як: О.А. Беляневич, А.Г. Бобкова, М.Д. Василенко, О.М. Вінник, С.Ф. Демченко, В.В. Джунь, В.О. Жаров, А. С. Нерсесян, М.І. Мельник, М. І. Аогвиненко, О. П. Орлюк, М.Ю. Потоцький, В.С. Щербина та ін.

Проте спеціальних досліджень проблем правового статусу промислової власності суб'єктів господарювання не проводилося, що і обумовлює актуальність нашого дослідження.

\section{Викладення основного змісту}

Аналіз цивільного і господарського законодавства свідчить, що основну увагу це законодавство приділяє регламентації статусу майна (матеріальним активам) особи, відповідним правовідносинам. Ще $з$ часів стародавнього Риму були дуже детально прописані (а у чинному Цивільному кодексі України відтворені) речові, абсолютні (за своєю природою) права. Ці права встановлюють панування особи (у тому числі юридичної) над речами (монопольну владу) і усувають усіх інших осіб від можливості впливу на ці речі. І вони (речові права) є абсолютними, оскільки монополі- зують владу особи над речами. Майно, по суті, є не лише об'єктом цивільних (господарських) прав, а й передумовою майнових правовідносин. Адже за відсутності в особи майна вона не може вступити у певні правовідносини, наприклад продати або заставити майно. Тобто участь у господарському обороті, здійснення господарської діяльності напряму залежить від наявності матеріальних активів.

Законодавець виходить $з$ припущення, що майно в особи завжди є. Це підтверджується вживанням у законі таких термінів, як «усе, що належить особі» i «на що може бути звернене стягнення». Тобто для права наявність у будь-якої особи майна $\epsilon$ презумпцією [2], а для суб'єктів господарювання наявність майна, майнова відокремленість є однією із загальновизнаних ознак, властивих усім організаціям [3, 4].

За умов, закріплених у чинному законодавстві, майно суб'єктів господарювання, будучи матеріальною базою їх діяльності, становить, як вважають дослідники корпоративних відносин, сутність статутного капіталу [5]. Це майно безпосередньо пов'язане і з правами, які надаються учасникам господарського товариства, зокрема, часткою в ньому. [6].

у Господарському кодексі України (ГКУ) майну суб'єктів господарювання, його правовому режиму присвячено окрему главу (глава 14 «Майно суб'єктів господарювання»), Як зазначається у ст. 139 «Майно у сфері господарювання», таким майном визнається сукупність речей та інших цінностей (включаючи нематеріальні активи), які мають вартісне визначення, виробляються чи використовуються у діяльності суб'єктів господарювання та відображаються в їх балансі або враховуються в інших передбачених законом формах обліку майна цих суб'єктів.

Згідно зі ст. 133 «Правовий режим майна суб'єктів господарювання», основу правового режиму майна суб'єктів господарювання, на якій базується їх господарська діяльність, становлять право власності та інші речові права. Суб'єкт господарювання, який здійснюе господарську діяльність на основі права власності, 
на свій розсуд, одноосібно або спільно 3 іншими суб'єктами володіє, користується і розпоряджається належним йому (ї) майном, у тому числі має право надати майно іншим суб'єктам для використання його на праві власності, праві господарського відання чи праві оперативного управління (ст. 134 «Право власності - основне речове право у сфері господарювання» ГКУ).

Цікаво відмітити, що величезна увага регулюванню матеріальних відносин, відносин, пов'язаних з майном і прав, що випливають 3 цих відносин відбувається на тлі того, що законодавець буквально у перших статтях Кодексу відмежувався від цього регулювання. Як зазначено уп. 4 ст. 3 «Господарська діяльність та господарські відносини» ГКУ, «Сферу господарських відносин становлять господарськовиробничі, організаційно-господарські та внутрішньогосподарські відносини». При цьому у наступному пункті (п.5 ст. 3) господарсько-виробничими є майнові відносини, що виникають між суб'єктами господарювання при безпосередньому здійсненні господарської діяльності. У той же час, у ст. 4 «Розмежування відносин у сфері господарювання з іншими видами відносин», сказано: «1. Не є предметом регулювання цього Кодексу: майнові та особисті немайнові відносини, що регулюються Цивільним кодексом України» (!?). Але повернемося до аналізу акцентування з боку господарського та цивільного законодавства на регламентації матеріальних активів, майна та майнових відносин.

Матеріальні активи, майно, як зазначає дослідник правового режиму майна установ І. П. Жигалкін [7], є показником можливостей, які можуть реалізувати дестинатори (одержувачі) юридичної особи - установи, та спроможності будь-якої організації відповідати за своїми боргами. Від обсягу майна особи залежить ії подальше існування, й у випадку недостатності в юридичної особи майна для розрахунків за своїми боргами (неплатоспроможність) може з'явитися така підстава для її припинення, як банкрутство. Досліджуючи теоретичні та практичні проблеми визначення складу «майна» як об’єкта цивільних правовідносин, С. І. Шимон зробив висновок про те, що внаслідок такого правового зв'язку між поняттями майна та правового статусу, який має юридична особа, ймовірно, і виник термін «майновий статус особи» [8]. Цей термін хоча і вживається в законодавстві, але вкрай рідко. При цьому під ним розуміється правовий режим майна.

Таким чином, майно суб'єктів господарювання відіграє ключову роль, будучи матеріальною базою їх діяльності. Воно визначає статус, правовий режим майна цих суб'єктів та безпосередньо пов'язане і з їх правами. При цьому під майном, як доведено вище, розуміють матеріальні активи. У той же час зараз, в умовах глобалізації, соціально-економічний розвиток України неможливий без урахування інноваційних процесів, що відбуваються в країні. Одним із ключових елементів протидії матеріальному прагматизму ринкової економіки, на наш погляд, $є$ розуміння економічної сутності, ролі, забезпечення просування та адекватного захисту нематеріальних активів і перш за все, такої ї головної складової, як право інтелектуальної власності. Це право є ключовим елементом у створенні інтелектуального потенціалу.

Згідно із Положенням (стандартів) бухгалтерського обліку, нематеріальний актив - це немонетарний актив, який не має матеріальної форми та може бути ідентифікований [9, С.10]. В українському законодавстві існують й інші визначення, за якими нематеріальні активи - це об'єкти інтелектуальної, у тому числі промислової власності, а також інші права, зокрема, такі, що пов'язані з користуванням землею, водою або інших природних і майнових ресурсів, спорудами і обладнанням тощо, включаючи право на інтелектуальну власність (патенти, технології, ліцензії), а у Податковому кодексі України [10] перераховані об'єкти права інтелектуальної власності. До них, зокрема, віднесені комп'ютерні програми, інші записи на носіях інформації, відео- або аудіокасети, кінематографічні фільми або плівки для радіо- чи телевізійного мовлення, передачі (програми) організацій мовлення, інші аудіовізуальні твори, будь-які права, які охо- 


\section{Цивільне, підприсмницьке, господарське та трудове право}

роняються патентом, будь-які зареєстровані торговельні марки (знаки на товари i послуги), права інтелектуальної власності на дизайн, секретне креслення, модель, формулу, процес, права інтелектуальної власності на інформацію щодо промислового, комерційного або наукового досвіду (ноу-хау).

Інтелектуальна власність є головною складовою інтелектуального капіталу.А у найбільш розвинених країнах саме цей капітал, інтелектуальна діяльність набувають сьогодні все більшого значення. При цьому це відбувається в різних видах діяльності суспільств. Темпи економічно-соціального піднесення в підсумку залежать від рівня інтелектуального потенціалу, особливо, промислової власності.

Промислова власність - це категорія, юридичний термін, яким об'єднується низка об'єктів інтелектуальної власності. Зокрема, до об’єктів промислової власності відносяться, по перше, такі результати інтелектуальної творчої діяльності, як винаходи, корисні моделі і промислові зразки. По-друге, це товарні знаки, знаки обслуговування, найменування місць походження товарів тощо. Усі ці об'єкти, як випливає зі статті 1 Паризької конвенції про охорону промислової власності від 20 березня 1883p., і охоплюються загальною назвою «Об'єкти промислової власності». [11] Конвенція поширює свою дію на територію України і розповсюджується не тільки на промисловість і торгівлю у власному значенні слова, але також і на галузі сільськогосподарського виробництва і добувної промисловості, на всі продукти промислового або природного походження.

Сдиного права промислової власності як юридичного інституту, який би опосередкував економічні, майнові відносини, пов'язані з промисловою власністю, у системі норм чинного законодавства не існує. Оскільки це так, тобто право промислової власності в об'єктивному сенсі не вирізнено, то можна казати про такий інститут лише в теоретичному плані, зокрема, у рамках цивільного законодавства. Право промислової власності можна розглядати як самостійний інститут разом 3 речовим правом власності. Це право представлено у вигляді низки відокремлених підінститутів, а саме: підінститутами патентного законодавства, законодавства про засоби індивідуалізації, а також законодавства про недобросовісну конкуренцію.

Щодо Господарського кодексу, то в ньому міститься спеціальна глава (глава 16), присвячена використанню у господарській діяльності прав інтелектуальної власності. У цій главі позначені об'єкти прав інтелектуальної власності (ст. 155), регулювання відносин щодо використання у господарській діяльності прав інтелектуальної власності, а також правомочності щодо використання окремих об'єктів цих прав (ст. ст. 156 - 162).

Позитивною вважаємо вказівку законодавця на те, що майнові права інтелектуальної власності на винахід, корисну модель, промисловий зразок можуть бути передані до статутного капіталу суб'єкта господарювання як вклад (п. 5 ст. 156).

У той же час ідея юридичного забезпечення просування, пріоритетної підтримки інтелектуального потенціалу, не проглядається в інших статтях ГКУ, які теж могли б бути пов'язаними із зазначеною ідеєю. Зокрема, у п. 3 ст. 139 «Майно у сфері господарювання», серед цінностей, які належать до основних фондів, не названі об'єкти прав інтелектуальної власності. Тим самим створено колізію між зазначеним положенням цієї статті і п. 5 ст. 156 «Правомочності щодо використання винаходу, корисної моделі та промислового зразка», згідно з яким «Майнові права інтелектуальної власності на винахід, корисну модель, промисловий зразок можуть бути передані до статутного капіталу суб'єкта господарювання як вклад»; теж саме протиріччя між зазначеним пунктом (п. 3 ст. 139) і п. 6 ст. 157 «Правомочності щодо використання торговельної марки». В останньому (п. 6 ст. 157) сказано, що «майнові права інтелектуальної власності на торговельну марку можуть бути передані до статутного капіталу суб'єкта господарювання як вклад». У Кодексі регламентовано правовий режим у сфері господарювання (вище вже аналізувалася 
ст. 133 «Правовий режим майна суб'єктів господарювання»), у т.ч. і особливості правового режиму державного майна у сфері господарювання (ст. 141 ГКУ). У той же час правовий режим інтелектуального потенціалу, особливо промислової власності, Кодекс не визначає і т.д.

Можна говорити і про відсутність юридичного забезпечення захисту немайнових прав суб'єктів господарювання. Так, ГКУ містить статтю 147 «Гарантії та захист майнових прав суб’єктів господарювання», у якій зазначається, що майнові права суб'єктів господарювання захищаються законом; вилучення державою у суб'єкта господарювання його майна допускається не інакше як у випадках, на підставах і в порядку, передбачених законом; збитки, завдані суб'єкту господарювання порушенням його майнових прав громадянами чи юридичними особами, а також органами державної влади чи органами місцевого самоврядування, відшкодовуються йому відповідно до закону; право власності та інші майнові права суб'єкта господарювання захищаються у спосіб, зазначений у статті 20 Кодексу тощо. Щодо немайнових прав, права IB, то спеціальних статей, присвячених їх захисту, організаційним механізмам забезпечення інноваційного розвитку, досягнення цілей підвищення частки IB у структурі активів підприємства - у Кодексі практично немає. Те ж саме можна сказати і про інші аспекти всього циклу життєдіяльності права інтелектуальної власності. Щодо спеціального регулювання (мається на увазі глава 16 ГКУ, присвячена використанню у господарській діяльності прав інтелектуальної власності), то положення відповідної глави в значній своїй частині носять декларативний характер, містять численні відсилання до чинного законодавства та Цивільного кодексу України. При цьому у главі 16 ГКУ найбільше відсилань до Цивільного кодексу. Чому так? На нашу думку, такий стан речей викликаний тим, що цілі нарощування інтелектуальної власності, захисту майнових прав саме на неї, на промислову власність, на винахід, корисну модель - чужі, далекі Господарському кодексу, ідеї якого, господарсько- правова концепція формувалися ще у соціалістичну добу, у 30-ті роки. Це був час становлення індустріального суспільства. Розвиток інноваційного сектору економіки з індустрією знань, з високою часткою у ВВП високоякісних та інноваційних послуг, з економічною конкуренцією в усіх сферах діяльності відбувся в останні десятиліття. Це і призвело до появи проблеми, яку потрібно вирішувати. Йдеться про наповненість господарського законодавства не тільки поняттями, а й ефективними організаційними механізмами забезпечення інноваційного розвитку, досягнення цілей підвищення частки IB у структурі активів підприємства.

Саме тому у господарському законодавстві i, перш за все, у Господарському кодексі, мають міститися положення, спрямовані на ефективну регламентацію усіх етапів життєдіяльності інновацій, забезпечення режиму найбільшого сприяння нарощуванню інтелектуального капіталу, розвитку промислової власності та тї захисту.

\section{Висновки}

Метою вдосконалення організації діяльності підприємств, суб'єктів господарювання має стати завдання нарощування їх інтелектуального потенціалу, інтелектуальної, промислової власності. Організаційним засобом вирішення цього завдання, забезпечення досягнення цілей підвищення частки IB у структурі активів підприємства має стати право, відповідні законодавчі норми. У той же час чинне законодавство України, зокрема, господарське законодавство, не створює найбільш сприятливий клімат для забезпечення економічної конкуренції продукції за рахунок нарощування промислової власності.

Аналіз цивільного і господарського законодавства свідчить, що основну увагу це законодавство приділяє регламентації статусу майна (матеріальним активам) особи, відповідним правовідносинам. Значна кількість положень ГКУ, присвячених промисловій власності, носить декларативний характер, не відповідають вимо- 


\section{Цивільне, підприсмницьке, господарське та трудове право}

гам повноти, несуперечливості правового регулювання. Необхідно наповнити основний, базовий документ господарського законодавства - Господарський кодекс не тільки поняттями, а й ефективними організаційними механізмами забезпечення інноваційного розвитку, досягнення цілей підвищення частки IB у структурі активів підприємства.

\section{Література}

1. В. Д. Дюндін, Інтелектуальна власність як головна складова інтелектуального потенціалу суспільства//

2. Ульяновська О. Правові фікції і правові презумпції: єдність та відмінність / О. Ульяновська // Право України. - 2005. - No 6. - C. 101-102.

3. Акіменко Ю. Ю. Майнова відокремленість юридичної особи приватного права у контексті сучасності / Ю. Ю. Акіменко // Науковий вісник Міжнародного гуманітарного університету. Серія: Юриспруденція. - 2013. - No 5. C. 104-106.

4. Форитор Т. М. Право власності як гарантія майнової самостійності юридичних осіб [Електронний ресурс] /T. М. Форитор. - Режим доступу: http:// nauka.kushnir.mk.ua/?p $=45846$.

5. Кравчук В. Поняття статутного капіталу юридичної особи / В. Кравчук // Право України. - 2006. - No 12. - С. 48-52.

6. Смітюх А. Щодо впровадження категорій корпоративного капіталу та оголошеного корпоративного капіталу господарських товариств до корпоративного права / А. Смітюх // Правова держава. 2014. - No 7. - C. 45-49.

7. Жигалкін I. П. Правовий режим майна установ / I. П. Жигалкін // Підприємництво, господарство і право. 2006. - No 7. - C. 103-106.

8. Шимон С. I. Теоретичні та практичні проблеми визначення складу «майна» як об'єкта цивільних правовідносин / С. I. Шимон // Вісник Академії адвокатури. - 2012. - No 1 (23). - С. 61-66.

9. Нематеріальні активи: правові та облікові аспекти: збірник систематизо- ваного законодавства.- К.: Бліц-Інформ, 2009.-Вип.6.-192с

10. Податковий кодекс України від 02.12.2010 № 2755-VI (Відомості Верховної Ради України (ВВР), 2011, № 13-14, № 15-16, № 17, ст.112)

11. Паризька конвенція про охорону промислової власності від 20 березня 1883 року (укр/рос). Набуття чинності для України: 25 грудня 1991 р. Аіга Націй; Конвенция, Международный документ от 20.03.1883 // Електронний ресурс. - Peжим доступу : http://zakon4.rada.gov.ua/ laws/show/995_123

Larin Vladislav Olegovich, Postgraduate student of the Department of Economic and Labor Law Institute of Law

APM LEGAL STATUS OF INDUSTRIAL PROPERTY OF BUSINESS ENTITIES

At the present stage of transition to the information society, the knowledge society in the leading countries of the world, intellectual property is considered as the main component of national wealth, the main factor of economic development. The purpose of improving the organization of enterprises, business entities should be the task of increasing their intellectual potential, intellectual and industrial property. The organizational means of solving this problem, ensuring the achievement of the goals of increasing the share of IP in the structure of assets of the enterprise should be the law, the relevant legislation. At the same time, the current legislation of Ukraine, in particular, economic legislation, does not create the most favorable climate for ensuring economic competition of products by increasing industrial property. Analysis of civil and commercial legislation shows that the main attention of this legislation is to regulate the status of property (tangible assets) of the person, the relevant legal relationship. The property of economic entities plays a key role, being the material basis of their activities. It determines the status, legal status of property of these entities and is directly related to their rights. In the context of globalization, the socio-economic development of Ukraine is impossible without taking 
into account the innovative processes taking place in the country. One of the key elements in counteracting the material pragmatism of a market economy is an understanding of the economic essence, role, promotion and adequate protection of intangible assets and, above all, their main component such as intellectual property rights. This right is a key element in building intellectual potential.

Intellectual property is a major component of intellectual capital. And in the most developed countries it is this capital, intellectual activity are becoming increasingly important today. Industrial property rights can be considered as an independent institution together with property rights. This right is represented in the form of a number of separate sub-institutions, namely: sub-institutions of patent law, legislation on means of individualization, as well as legislation on unfair competition. The Commercial Code should contain provisions aimed at the effective regulation of all stages of innovation, ensuring the regime of the greatest assistance to the growth of intellectual capital, the development of industrial property and its protection. Analysis of civil and commercial legislation shows that the main attention of this legislation is to regulate the status of property (tangible assets) of the person, the relevant legal relationship. A significant number of provisions of the CCU on industrial property are declarative in nature, do not meet the requirements of completeness, consistency of legal regulation. It is necessary to fill the main, basic document of economic legislation - the Commercial Code not only concepts but also effective organizational mechanisms to ensure innovative development, achieving the goals of increasing the share of IP in the structure of enterprise assets.

Key words: business entities, intellectual property, industrial property, knowledge society, property law, patent legislation, legislation on means of individualization, legislation on unfair competition. 